A Journal of Culture, English Language, Teaching \& Literature ISSN 1414-3320 (Print), ISSN 2502-4914 (Online)

$$
\text { Vol. } 18 \text { No.1; July } 2018
$$

Copyright (C) Soegijapranata Catholic University, Indonesia

Falling for The Troll: A Children's Literature Study on Holly Black's Valiant: A Modern Tale of Faerie (2005)

${ }^{1}$ Alberta Natasia Adji and ${ }^{2}$ Athaya Prita Belia

${ }^{1}$ Master of Literature and Cultural Studies, Faculty of Humanities, Airlangga University, Surabaya, Indonesia

${ }^{2}$ English Department, Faculty of Humanities, Airlangga University, Surabaya, Indonesia

email: ${ }^{1}$ alberta.adji@gmail.com; ${ }^{2}$ ayapritabelia@gmail.com

Received: 31-05-2016 Accepted: 02-06-2017 Published: 15-07-2018 


\title{
Falling for the Troll: A Children's Literature Study on Holly Black's Valiant: A Modern Tale of Faerie (2005)
}

\author{
${ }^{1}$ Alberta Natasia Adji and ${ }^{2}$ Athaya Prita Belia \\ 1ªlberta.adji@gmail.com; ${ }^{2}$ ayapritabelia@gmail.com \\ ${ }^{1}$ Master of Literature and Cultural Studies, Faculty of \\ Humanities, Airlangga University, Surabaya, Indonesia \\ ${ }^{2}$ English Department, Faculty of Humanities, Airlangga \\ University, Surabaya, Indonesia
}

\begin{abstract}
Monsters have always been a part of children fictional tales, representing the evil side of nature. They are the reason why heroes and heroines struggle to fight against, but at the same time they balance the whole realm, existing side by side with the heroes. There have been numerous children stories which depict the monsters as the villains, but they have rarely done so in portraying monsters as the wronged ones. In Holly Black's Valiant (2005), the troll character named Ravus is presented as an outcast, a banished figure from his folk because of a misjudged rumor in his former kingdom. Unlike others who constantly challenge and trap humans, Ravus becomes a scholar who loves to explore his alchemy. He helps other outlaws to secure their well-being and health, even teaching Valerie the protagonist with her sword practicing, rescuing her whenever possible and eventually falling for her. The study highlights a new perspective on monstrous identity in a young adult book, making a counterpoint in presenting a fact that monsters can also be portrayed as very human and gentle instead of rude and dangerous.
\end{abstract}

Key words: children's literature; monstrous identity; outcast portrayal

Abstrak: Monster telah lama muncul dalam banyak kisah kanakkanak, merepresentasikan sisi jahat dari alam. Monster seringkali menjadi alasan bagi para tokoh pahlawan untuk bertarung, tapi di sisi lain keberadaan mereka menyeimbangkan keseluruhan alam 
172 Celt: A Journal of Culture, English Language Teaching \& Literature, Volume 18, Number 1, July 2018, pp. 171 - 187

dan mampu berdiri berdampingan dengan keberadaan para tokoh pahlawan. Ada banyak kisah kanak-kanak yang menampilkan monster sebagai tokoh jahat, namun tidak banyak kisah yang menampilkan monster sebagai pihak yang tersakiti atau korban. Dalam novel Valiant (2015) karya Holly Black, karakter trol bernama Ravus ditampilkan sebagai orang buangan, sosok yang disingkirkan oleh kaumnya karena sebuah fitnah yang beredar di kerajaan asalnya. Tak seperti tipikal tokoh monster yang terbiasa melawan dan menangkap manusia, Ravus justru menjadi cendekiawan yang senang mendalami ilmu alkemi. Ia sering membantu tokoh-tokoh pelanggar hukum yang dibuang dan terasing dengan membuat ramuan untuk menjaga kesehatan mereka, bahkan mengajari Valerie sang tokoh utama bertarung dengan pedang, menyelamatkannya di banyak situasi berbahaya dan bahkan pada akhirnya menyukai gadis itu. Artikel ini menggarisbawahi sebuah perspektif baru terhadap identitas 'mengerikan' yang kerap disematkan pada tokoh monster dalam sebuah karya sastra untuk remaja, menegaskan fakta bahwa tokoh monster sekalipun dapat direpresentasikan sebagai sosok dengan sifat-sifat manusiawi yang lemah lembut, bukan sebagai pribadi yang kasar dan berbahaya.

Kata kunci: sastra anak; identitas 'mengerikan' yang sering disematkan pada tokoh monster; penggambaran tokoh yang terasing

\section{INTRODUCTION}

In most contemporary Young Adult (YA) books, themes like love, discord, immaturity, betrayal, friendship, and rebellion are all familiar with how they are carried out within the narrative. Of course, this does not mean that the issues found in there are not entwined with the usual genres that any work of literature takes. Being one of the most prominent is fantasy, it allows readers to enter another realm, bringing the great unexpected so close to them that it may be enabled access throughout simple everyday things that actually mask this ominous existence of another, regardless the consequences.

Incorporating dual versions of exteriors, fantasy is a literary genre that is heavily considered to resemble folklore or fairy tales, only much more extended or elaborated in long retellings. It presents a scenario with a range of wild creatures as characters but acting with human qualities as well as emotions. Both fairies and monsters unfailingly fall to this category, projecting the traditional relationship between animal and human in the way they deal with 
each other. While fairies tend to be portrayed as unworldly idyllic, graceful, magical, glamourous, untouched, and deceiving, monsters are doomed to be primitive, volatile, brutal, cruel, violent, unsympathetic and above all, dangerous. Generally, they cater for vampires, werewolves, fairies (for some wicked ones), goblins, trolls, and other metaphysical or astral beings.

Adjoining YA literature, Holly Black establishes her reputation as a fiction writer by creating fairy stories filled with monstrous figures. Born in 1971, Wench Long Beach, New Jersey, she had spent her childhood with a mother who was an avid reader of fairy and ghost stories, also a painter and doll maker, in an old Victorian mansion that heavily supports her fantasy imagination while writing her novels (Black Author's Profile). So far, she has penned YA novel series, short stories, middle-grade stories, graphic novels, and a collection of poetries with many awards followed. The most notable is her series of middle-grade mini novels which have been made into a movie, The Spiderwick Chronicles. Among her early YA novels, the Trilogy of Modern Tale of Faerie, Tithe, Valiant, Ironside, stands out as a fresh perspective on the shared universe between mundane and fairies. Valiant in particular made Black a Winner of the Andre Norton Award for young adult fiction from the Science Fiction and Fantasy Writers of America, an ALA Best Book for Young Adults, with two more book selected awards from Locus Recommended Reading List and New York Public Library Book.

The second instalment, Valiant (2005), resides in the same faerie world like the first volume, Tithe (2002), only that it concerns a different heroine named Valerie who stumbles upon the faery realm right after she discovers her mother's affair with her boyfriend and escapes from home. Told in a third person point-of-view, she comes across a group of street kids who show her how to use glamour, an addictive drug that is used by faeries so they can keep their human exterior while being exposed outside.

Caught between several rough incidents, Val finds herself torn whether she should come back and forgive her mother, or continue to live as a street gang member and work as a courier for the honorable troll she has come to love. Ravus, the troll, is an expert in both medicine and sword fighting who lives in the human world as an exile. He has been long trusted as drugs and potions maker, creating healing ones for other fairies to protect themselves from iron and the prying eyes of humans. When another exile, a she-faun, frames him for a series of uncommitted murders, Ravus does not have any other choice than letting Val to be the one who commits his innocence against the Faerie Court and eventually saves his life. 
174 Celt: A Journal of Culture, English Language Teaching \& Literature, Volume 18, Number 1, July 2018, pp. $171-187$

In that notion, the study aspires to discuss the projection of monstrous identity of Ravus, the troll from the faerie kingdom in Holly Black's Valiant: A Modern Tale of Faerie. Out of other possible faerie characters in the book, Ravus is selected for his different personality and capability although he is of immortal faerie blood. He can be very thick and proud and a bit of misanthrope or loner most of the time, but once Val gets to know him and fall in love with him, Ravus is actually a tender and caring figure to those he cherishes best. Although his current status in third half of the novel is a disgraced exile who cannot return to his own homeland in the Court, he is actually just a wronged man who was trapped at the wrong time, as he was accused of murdering his only best friend Tamson in a duel. Thus, Ravus's portrayal as a faerie monster and his relationship with the only human he loves, Valerie, is investigated in detail.

The analysis or discussion will only cater for Ravus's two issues since the other monstrous faeries behave quite in the same brutal or rude way, which is already common and mostly expected of them. What is more, the study is written using a descriptive-qualitative method because the evidences embedded in it are all analysis writings, direct quotations, and citations. It is focused on revealing the monstrous identity of Ravus the troll presented in Holly Black's Valiant: A Modern Tale of Faerie, and proves whether Ravus's portrayal of a monster affect his relationship with Valerie, the only human he loves, in Holly Black's Valiant: A Modern Tale of Faerie.

\section{LITERATURE REVIEW}

The knowledge associated with monster in YA literary works, Classen (2013) pays attention to the reflections of beasts found in medieval literary masterpieces from Beowulf to Melusine, stating that in a way monsters should be taken deeper into their epistemological function in the narrative rather than the morality, as they consistently contribute to the development of individual protagonists in the stories. What is thought further, these monsters actually represent the negative side of the heroes themselves, so that they can recognize their darker side whilst undergoing a struggle in the journey of ever existing battle between the light and the dark (Classen, 2013, pp. 521-522).

Similarly, Doll (2011) finds the same thing when she relates the cannibalism issue embedded in the plot of Greek Myth with the sins of the United States' controversial criminal Jeffrey Dahmer. She highlights the crucial demonism that emerges because of the failed relationship with the daimon, 
which in myth she describes as the fate that calls to someone (Doll, 2011, p. 23). It means that when someone becomes a criminal or a 'monster' in real life is because he/she cannot accept their own daimon, finally choosing rebellion and setting themselves in the wrong path of life, becoming the accursed enemy of the society.

Third and likewise, Russell (2010) posits how demonic monstrosity is much more likely to be figurative than literal. He presents the argument whether some certain people are born in pure evil, corroborating with the belief if some individuals are truly representing the banality of evil and thus unable to change it because it is just the way the nature is. Although the majority of people in society commit criminality just because of bad choices, everyone should be aware that some or several individuals do not seem to possess the light side in their personality, in a way that they only yearn to relentlessly grind people with pleasure, disregarding the moral and ethics codes that each of people should adhere to (Russell, 2010, pp. 45-46).

Enclosing the review, Bradford (2013) implies that monstrous identities in YA literature include the worshipped vampires, discriminated werewolves, wicked fairy mothers, and greedy incestuous fathers who want to marry their beautiful daughters. Focusing prominently on Stephenie Meyer's The Twilight Saga, the vampires and the werewolves are oppositions depicted as the Western white and the Native American non-white communities, in which the author herself and the readers preferring the first. This is not surprising since vampires are usually very pale, seductive, and having superhuman strength, and of course their appearance is still human, only much more interesting.

On the other hand, though werewolves are the ones that truly have the equal superhuman strength like vampires, they are just placed as second best because they are shape-shifters, taking the transformation form of a wolf, a wild animal (Bradford, 2013, pp. 115-116). As for fairy stories or novels, the Fairy Queens are usually portrayed as wicked, cold-hearted, ambitious, and a sole tyrant even to their own children.

The last, some fathers in famous fairy tales are obsessed with their charming wives that they refuse to marry any other woman other than their own wife-like daughters, performing incestuous relationships (Bradford, 2013, pp. 120-123). 
176 Celt: A Journal of Culture, English Language Teaching \& Literature, Volume 18, Number 1, July 2018, pp. $171-187$

\section{DISCUSSION}

\section{A. The traumatic family past}

Belonging to a Fairy Folk many years ago, Ravus was born from a troll mother and a human father. He tells Valerie or Val that he had a complete family once when they were still living in a small forest in Iceland together. His troll mother was recalled to be very graceful and dazzling, having very good, icing-like hair that glowed like bejeweled fire, burning under the sunlight (Black, 2005, pp. 58-59). She fell in love with her husband, a human, and agreed to marry him and gave birth to his children.

However, she had to keep her own identity and the children as monster in the dark, since most humans are paranoid toward those who are completely different to them, especially magical or astral beings like faeries. Somehow it is a bit ironic since monsters like trolls are rare to be blessed with such great beauty, but the one female troll who possessed that must refrain herself in full awareness from displaying it to the only man she loved the most. Her true existence as an ominous faerie was not an appraised privilege but a feared curse to the eyes of the humans including her own beloved husband:

"Despite all that beauty, my mother never showed her true self to my father. He was mortal, like you, and around him, she always wore a glamour. Oh, she was beautifully glamoured, too, but it was a muted beauty. My brothers and sisters-we had to wear it, too." (Black, 2005, p. 159)

His father, a mundane or a human, was mortal and he had another human family back in town but none of his parents ever made a fuss out of it. On the other hand, his mother performed some tricks to not letting her husband know who they all were. In order to maintain the harmony of the family, he and all of his siblings had to hide their true physical identity as faerie monsters, pretending to be humans (Black, 2005, p. 160). Neither of them could expose themselves freely to their biological father, which is quite ridiculous and somehow pitiful, because their mother had refused to show herself for what she really was before her marriage. Perhaps if her mother had defined her status as a faerie troll years ago at her first encounter with her husband, there is a possibility that her and her children would always be accepted and not avoided in fright by their own father after all. Perhaps Ravus's human father would even respect his troll wife's bravery for loving and committing herself to an ordinary human man, providing every comfort for him and their offspring. 
According to Ravus's retelling, his mother had requested her husband to signal his arrival with the bell so that they could wear their glamour and thus not making him frightened with their monstrous appearance. But of course, just like in classic fairy tales, the worst has to happen: "One day my father forgot to ring the bell... He saw us all as we really were. And fled, never to return." (Black, 2005, p. 160)

There is no doubt that their identity was entirely rejected and denied. Once again, the old fear of things and beings that cannot be explained shared among humans had won. Though their harmonious family life had been finely wrought, it was all ruined in a split second, throwing his mother into the furor of hate and bitterness. It was never the same again for them. His mother was all in rage and spiteful, blaming it the unfortunate to her own children although Ravus had been sure that inwardly she must had known that it was inevitable to happen, since most covered-up things are surely bound to be found, one way or another (Black, 2005, pp. 160-161).

The trauma in his mother's failed trust to his father plays a big factor in his lonely upbringing in the next years. Ravus still keeps himself calm and preserved but he cautiously chooses to move on and live alone in the Bright Court, only coming out at night since he, as a troll, is naturally nocturnal. His family or siblings are only mentioned at the story when they were still living in the far woods of Iceland, indicating that none of them keeps in touch with each other upon reaching adulthood. This somehow makes it clear that he prefers to live as a sole individual rather than keeping a company (be it his siblings or friends), including his early reluctance to response to Val's affection for him.

\section{B. The sensitive misanthrope}

In their first meeting, Val breaks into Ravus's house in the old and abandoned corner of underground subway tunnel with Lolli out of curiosity. She stumbles upon a corridor within it, revealing a chamber that is full of dangling thick roots, which are unnatural because they have ripe fruits even though there is no sun and soil to feed them. There were also "rusted stairs, their railing wrapped with sodden cloth, (Black, 2005, p. 83)" that lead to the working room of the troll. In that room, Val sees piles of dusty ancient books, a makeshift desk for experimenting, and a made-of-glass sword. What is more, Lolli is then attacked with a boneless white doll that is meant to be the guardian of that small place, finally arousing Ravus into scene (Black, 2005, pp. 84-85). This implies that the troll Ravus does not desire his place to be easily 
178 Celt: A Journal of Culture, English Language Teaching \& Literature, Volume 18, Number 1, July 2018, pp. 171 - 187

found and interrupted by anyone, particularly curious humans. He prefers it to be well hidden and difficult to be found, whether or not someone means to or in an accidental moment. Even his style of dressing is very conservative and pallid in taste, wearing "a buttoned black coat that covered him from neck to calf, with black trousers underneath that seemed to emphasize the shock of green at the frayed cuffs and nape where cloth met flesh, (Black, 2005, p. 86)" that highlights his locked, introverted self.

Ravus is angry and cross when he sees Val and Lolli poaching into his hidden place, threatening them physically by twisting Lolli's finger as a painful reminder not to wander among someone else's property, since he finds out that Lolli has just stolen some of his glamour medicine jars into her backpack. He also condemns Val to atone her prank by bounding her as a deliverer. His harsh reaction is actually typical for anyone who has just red-handedly caught up some stray intruders in his/her home and stealing things that are not theirs. As there is only one human, Luis, who works as his courier to other faeries, he interrogates them what Luis has told them about him and his place. Ravus accuses them being curious about wanting to see a real monster as a childish dare-to-see game or challenge. He accuses them to be answering some foolish challenge from Luis, to see if the monster, Ravus himself, is cannibal or dangerously carnivorous just like the spooky monsters in children fairy tale books:

The troll took another step toward them, his voice soft and furious. "Did he dare you to go inside? Did he say there was a monster?"

Val looked at Lolli, but she was stunned and silent.

The troll ran the point of his tongue over an incisor. "But what did Louis intend, that's the real question. To give you a good scare? To give me a good scare? A good meal? It is entirely possible Luis might think I would want to eat you." He paused, as if waiting for one of them to deny it. "Do you think I want to eat you?" (Black, 2005, p. 87)

Still, with those challenging but demanding questions, it is proven that Ravus is actually no brute, not even close. Perhaps he is just a little bit sensitive since his status as a monster who lives among humans has made him very cautious and above all, suspicious. He only wants to know the truth if his human courier Luis is still loyal to him or not, and make the two girls responsible of their actions. Of course, he also intends to warn them not to deal with things that 
are not their business and obviously out of their league, just for their own good sake.

Fairies are indeed enchanting, but so do their cruelty and cunningness. It is actually very lucky of both girls to be meeting such much lenient creature, in which they can escape with just a minor finger fracture for Lolli and a delivery contract task with Val because she is the one who chooses to hold the responsibility, making her status as the same as Luis now, only under threat:

He sighed. "You will serve me for a month, one week for each item stolen." Pausing for a moment, he added, "In whatever way that I need."

She flinched and he smiled.

"Each dusk you will go to Seward Park. There, you will find a note under the wolf's paw. If you do not do what it says, things will go hard with you. Do you understand?" (Black, 2005, p. 90)

When it comes to living as an exile, he prefers to do it all alone without anyone interfering, except for some occasional guests like Luis his courier and Mabry, his late friend Tamson's ex-lover. If he needs to contact another faerie outside who also dwells in the urban city corners, he just passes his message through Luis or uses black birds to deliver them. Ravus is not the only exiled faerie in New York, but he separates himself from the rest of his folk so that no one can disturb him from his medicine work. He prefers to be the misanthrope healing drug provider who sends his ailment indirectly to others. This behavior does not come for him as an ashamed feeling of living as an exiled member of honorable Fairy Court, but it had always been his choice long even before that.

When he was still new to the Bright Court or Seelie Court, he chose experimenting with his potions rather over dueling like any other decent gentleman faerie in the kingdom, although he is very much able to fight with his accomplished sword skill:

"The Queen of the Bright Court likes fighting best of all the sports. She would organize tournaments where the Folk could show off their skill. I was new to the court and I did not much like to compete. My delights came in my work, my alchemy." (Black, 2005, p. 166)

Nonetheless, when Val finds herself starting to fall for Ravus and unthinkingly tries to be intimate with him just a little, he brushes her off abruptly as part of 
180 Celt: A Journal of Culture, English Language Teaching \& Literature, Volume 18, Number 1, July 2018, pp. 171 - 187

his fear of close intimacy between lovers, a childhood trauma that still reminds him of his mother's failed marriage to his father (Black, 2005, p. 196). Val, who is quick to read him, feels hurt and she wanders aimlessly until she gets another chance to meet him in a faerie night party, though it is accidental. Ravus treats his feelings coldly though he cannot deny his inevitable attachment to her. Still, most of the time, particularly through Val's eyes, he is very distant and guarded of his emotions, never letting them pour out of control. It is obvious that Ravus has always been so used of being alone that he still feels the urge to assure himself that he is still an adherent to it. As a lone survivor, he does not trust new things easily and that includes his own growing love to a human girl.

\section{A wronged paragon}

Once having a dear friend, Tamson's sudden death by Ravus's own hands still haunts him in most of his choices. Ravus keeps the sword that has killed Tamson unexpectedly in his work room, to remind him so that he will never repeat the same mistake again (Black, 2005, p. 123). He claims to Val that he is an excellent swordsman, having been trained by his own mother and siblings back then on his childhood days. They taught him to feed his fury with fighting, thus leading him to be very aggressive in duels.

Finally, the worst chance came as Tamson proposed a duel with him to win back Mabry's heart, never truly suspecting that the woman did some cunning trick to his armor, making it terribly easy to breach by just one single stroke of Ravus' sword, finally ending Tamson's life and sending Ravus into choosing the life as an exile:

"Tamson's armor was formed from bark, magicked to be harder than iron." He stopped speaking, closed his eyes and started up again. "He was a better swordsman than I, but he was distracted and I struck first. The sword, it cut through the bark like it was paper." (Black, 2005, pp. 166-167)

Becoming an expert in the field of medicine, Ravus is trusted by the exiled communities to send them healing potions to ease their pain after contacting their skin with iron (Black, 2005, p. 125). This is why he needs human couriers such as Luis and Val, since he naturally cannot go out in bright daylight to deliver them himself. However, this has become a double-edged sword for him because Luis secretly entrusts some of the deliveries to his reckless brother Dave. 
Though Luis also never expects his brother to betray him, in fact he does. Mabry, who wants to claim her place once more in the Faerie Court, tries to make Ravus a scapegoat once more, this time in poisoning others, compromising with Dave. She quietly inserts poison in Ravus's ailment that is going to be transported by Dave, so that the other faerie folks will be dead one by one. Unbeknown to him, Ravus is once again confronted and punished for the crimes he never commits. All this time he has remained true to himself and gentle toward others, but he is still wronged.

\section{The gentle monster lover}

Seeming menacing both in appearance and personality at first, Ravus quickly becomes a figure that Val respects and eventually loves. Although technically she is nothing but a rude poacher, the troll seems having no resentment or reluctance in answering her curious questions. He even explains to her in detail before delivering the medicine, to make her much informed and careful, that the exiled faeries are divided into some courts and occupy some territory, occasionally fighting those from nearby Courts, which are Bright Court or Seelie Court and Night Court or Unseelie Court (Black, 2005, pp. 126-127).

Not only that, he also gives her some magic protection and good advice before setting off, so that she will not be lured into unnecessary traps by these cunning faeries, something that is rarely found in a monster master to his street messenger. Ravus does not harshly exploit his courier like a slave, but instead he treats Val with respect, politeness, care, and gentle guidance while initially she thought him to be a tyrant. He always makes sure that the journeys she is going to take are secure and manageable.

When Val later reports to him that she has found a murdered mermaid by the river, he comes to see it himself with Luis and Val as company. There, he gets confronted and challenged in a duel by some rude ogre faerie community, but ends up being saved by Val who throws herself in front of him to accept the blade in her leg. In a delirium state after stabbed, she is awakened by Ravus's tight grip on her arm, being confused of who he is since he clothes himself in glamour, but finally recognizes him and earns his mutual friendship after all:

$$
\text { "Val,” Luis said. "It's Ravus. Ravus.” }
$$

"Don't touch me," said Val, wanting the pain to stop. 
182 Celt: A Journal of Culture, English Language Teaching \& Literature, Volume 18, Number 1, July 2018, pp. 171 - 187

A bitter smile touched his mouth as his hands left her. "You could have died," Ravus said quietly.

Val took that as an encouraging sign that she wasn't actually dying. (Black, 2005, p. 155)

Ravus takes care of her and nurses her back to health, as well as answering all of her questions about his work, his magical healing ailments, his origin, his past, his possession, his difficulties living in human world's city-in short, almost all aspects of his life-without getting annoyed at the slightest, even enjoying playing the knowledgeable teacher to his most favorite and critical pupil from time to time. He always has patience for Val no matter what, being a dependable figure to her, replacing the empty hole that is supposed to be filled with Val's dysfunctional egoistic parents and jerky ex-boyfriend.

As he is faced with a growing love, Ravus regards it as a gentle mutual affection that is normal to occur between two gender-different coworkers. However, in rare moments he shows his care for her through small, simple gestures of focused attention:

She reached one hand toward him and he took it, running his fingers over her calluses. She looked up into his face, trying to convey her sympathy, but he was looking intently at her hand.

"What are these from?" he demanded.

"What?"

"Your hands are rough," he said. "Calloused."

"Lacrosse," she said.

He nodded, but she could tell from his face that he didn't understand her. She might have said anything and he would have nodded that way.

"You have a knight's hands," he said finally and let go of her.

Val rubbed her skin, not sure if she was trying to erase the memory of his touch or to recall it. (Black, 2005, pp. 169-170)

Realizing the dangerous impact that will fall upon his precious messenger, Ravus intends to repay Val's sacrifice by setting her free of the servitude right away. However, Val has a different perception and asks to be 
mentored in sword fighting instead, also wanting to be his courier still (Black, 2005, pp. 170-171). Without further ado, he accepts her request, promising that he will teach her to be a brutal fighter as she wishes. He is greatly indebted to her, thus any kind of unpleasing demand from her costs little to him. In short seconds, he shows concern and regret that Val has asked such thing that would surely make her a bad human being, slightly indicating his growing attachment to her.

He conceals it through his snapping at her while Val is disorientated on failing to block his attack, hitting her head strongly by the wall (Black, 2005, pp. 189-190). He is actually not angry at her but more at himself for letting her learn something too hard and hurting. Just like most men who cherish the women they love, they tend to protect their female partners from doing dangerous things that are likely to cause injuries or accidents. Interestingly, he has never denied it bluntly in words, only in abrupt self-drawings from her each time after one sudden close physical contact after the long tiring days which they are engaged in sword fighting exercises together:

His eyes were half-lidded as he pushed himself off the desk, their bodies sliding together, his hands still holding hers. Then, suddenly, he froze.

"Is something-," she started, but he pushed away from her abruptly.

"You should go," he said, walking to the window and then just standing there. She knew he dared not part the blinds while it was still day outside. "Come back when you are feeling improved. It does neither of us any good to practice when you're sickly. If you need something, I could-”

"I said I was fine." Val's voice pitched louder than she'd intended. (Black, 2005, p. 196)

When Val wanders aimlessly at the Folk party of exiled faeries, she runs into Mabry and then Ravus. He pretends to be flirting with her shortly, surprising her with his disguise and his annoying warning of her coming there. Somehow Val becomes much more glad and calm after knowing how much he cares about her by reading between the lines of his words.

Ravus belongs to the type who likes to lecture his beloved person to restraint himself from making the first move rather than romancing her directly 
184 Celt: A Journal of Culture, English Language Teaching \& Literature, Volume 18, Number 1, July 2018, pp. 171 - 187

through intimate or seductive physical contacts. As a decent figure, he honors old ways of encountering the opposite gender so he is still not used to displaying obvious affection to the young woman he holds dear. Still, Val, who is a modern-born girl, rebels by kissing him passionately and somewhat forces him to admit his feelings for her, though implicitly (Black, 2005, pp. 230-231). Ravus turns his face away in shock, but he confesses that he likes the kiss, conveying the love he has nurtured for her is finally shown. Wanting to avoid it, he insists on accompanying her home, but Val interposes and thus makes him deal with their inevitable attraction toward each other. Ravus finally states his fundamental reasons to forget whatever it is between them:

He spread his hand as though trying to express something inexpressible. "We both know that I am a monster."

"You're not-"

"It demeans you to cover rotten meat with honey. I know what I am. What would you want with a monster?"

"Everything," Val said solemnly. "I'm sorry I kissed you-it was selfish and it upset you-but you can't ask me to pretend that I didn't want to." (Black, 2005, p. 232)

At last, right before he is charged as the serial murder of mysterious deaths happening around the exiled Courts, Val bravely points out how much Ravus means to her, telling him how she loves his fascinating gold eyes and never minding his monstrous appearance. Both are a little bit awkward with their feelings, yet nevertheless they are mentally ready to accept them. Incredibly, Ravus responses positively as he seems pleased with her unexpected comments:

He snorted with amusement, but stayed still.

She reached up and touched the pale green of his cheek. "I like all the things that make you monstrous."

His long fingers threaded through the peach fuzz of her hair, clawed nails resting carefully against her skin. "I'm afraid that whatsoever I touch is spoilt by the contact."

"I'm not scared of being spoiled," Val said.

The side of Ravus's mouth twitched. (Black, 2005, p. 233) 

Holly Black's Valiant: A Modern Tale of Faerie (2005)

When Mabry interferes with her wicked schemes, the goat-hooved faerie manages to separate the budding romance between them and fatally injures Ravus when she tears his heart out of his chest to bring it as a proof to the Bright Court (Black, 2005, p. 267). Enraged, Val vows to defeat Mabry and return his heart back in time after turning Ravus into stone under unshielded sunlight. After going into a hard battle that is watched by the entire Folk of Dark Court, Val finally sends Mabry to her death and hurries back to Ravus's place, only to find that his life is no longer there. Fortunately, fate is kind to both of them since Ravus awakes right after Val kisses him, coughing but alive once more. They rekindle their relationship in a much calmer situation:

He pulled her close, hands careful not to touch her wounds as they wrapped around her. "I hope that you feel for me as I do for you," he said, his voice like a sigh against her throat.

"And how is that?" she asked, her lips so close to his jaw that she could taste the salt of his skin when she moved them.

"You carried my heart in your hands tonight," he said. "But I have felt as if you carried it long before that."

She smiled and let her eyes drift closed. (Black, 2005, p. 307)

Finally, all is settled and that Val has gone back to her old life with her mother and best friend Ruth, Ravus sends his black bird to deliver his message to his new human lover, always informing her of what is going on with Luis, Dave and the Faerie Court. She keeps the habit of waiting news from him, and this time the note tells her that he wants to meet her that night at her school backyard, promising to give her a gift. Val is glad with this but she jokingly signifies to Ruth that she will never be able to introduce Ravus to her mother, as he is an ogre who lives in an underground subway.

Later, she comes to him and finds that Ravus is bringing her a true sword that is made up of iron, just so she can protect herself from evil faeries (Black, 2005, pp. 310-311). She recites her plan into entering university in New York to be closer to him, and that she wants her sword lessons to continue again just like before. Val also asks if Ravus will return to the Bright Court since he is now a free and innocent man, but he rejects the idea by staying in the human world so that he can always be near to her as long as he can. Ravus is indeed a gentle figure, always so caring from start to finish, even in the slightest things. 
186 Celt: A Journal of Culture, English Language Teaching \& Literature, Volume 18, Number 1, July 2018, pp. 171 - 187

\section{CONCLUSION}

Belonging to the Faerie Folk, Ravus is destined to be the troll who somehow always ends up living all by himself. Although he possesses regrettable pasts involving his mother's ruined marriage and his friend, Tamson's death, Ravus never uses them as a reason to behave badly or brutally against others in his adulthood. He just quietly resumes his favored work in alchemy and keeps minimum contact with the outside world as an exile. Faeries are supposed to be cruel, tricky, and ignorant of humans, but Ravus are obviously none of these things. He goes as far as being generous in giving his potions freely to other suffering faeries, saves Dave's life, shows Val mercy, takes care of her, mentors her well, and eventually loves her.

Clearly different from what typical portrayal of monstrous faeries, as a troll Ravus is unrelentingly cultured, highly educated, very skilled and terribly gentle especially toward those he loves. Even his way of speaking to Val when she has already become his lover is never rude or obscene. Of course, he still has the fury of troll monster when in fights, but most time he never crosses the line or behaves wildly and astray like his majority other species. In fact, despite his obvious monstrous appearance, he resembles humans in many ways, particularly in his honorable character. What shields him from Val is only his past trauma and low self-esteem in his own monstrous physical appearance that makes him thinks that he is unworthy of her affection.

Meanwhile, Val sees him as a true man who is not only wise and highly skilled in many things, but also excellent in his moral values and personality, far better off compared to her own divorced parents and former boyfriend. She respects and looks up to him as a paragon as well as a lover, thus thinking that falling in love with Ravus might be the most sensible thing she has ever done.

\section{REFERENCES}

Black, H. (2005). Valiant: A modern tale of Faerie. New York: Simon \& Schuster Children's Publishing Division.

Bradford, C. (2013). Monsters: Monstrous identities in young adult romance. In (Re) imagining the World (pp. 115-125). Berlin, Heidelberg: Springer.

Classen, A. (2013). The monster outside and within: Medieval literary reflections on ethical epistemology. From Beowulf to Marie de France, 
Adji, A. N. \& Belia, A.P. Falling for the Troll: a Children's Literature Study on 187 Holly Black's Valiant: A Modern Tale of Faerie (2005)

the Nibelungenlied, and Thüring von Ringoltingen's Melusine. Neohelicon, 40(2), 521-542.

Doll, M. A. (2011). The Monster as Other, as Self. The More of Myth (pp. 23 39). Springer.

Russell, L. (2010). Evil, Monsters and Dualism. Ethnic Theory Moral Prac, 13 (1), $45-58$. 